When symptoms persist after glasses have been prescribed the eye strain is probably due to convergence insufficiency and not to refractive error. It would help if all patients supplied with glasses under the general ophthalmic service of the National Health Service were given a form advising them to see their doctor again if their symptoms are not relieved. The cause of their condition would then be recognized and treatment arranged.

Duke-Elder, S. (1969). The Practice of Refraction, p. 157. London, Churchill.

\title{
Rapid Blood Ketone Body Estimation in the Diagnosis of Diabetic Ketoacidosis
}

\author{
K. G. M. M. ALBERTI, T. D. R. HOCKADAY
}

British Medical fournal, 1972, 2, 565-568

\section{Summary}

Different methods of assessing ketone body concentrations in blood and plasma of ketoacidotic patients have been compared. We confirmed that Ketostix reacts strongly with acetoacetate, giving a useful range of 0 to $10 \mathrm{mM}$ for plasma acetoacetate, that acetone reacts weakly, and that 3-hydroxybutyrate does not react at all. Plasma Ketostix readings correlated only moderately well with enzymatically determined whole-blood acetoacetate. All samples giving a +++ reaction contained more than $1.6 \mathrm{mM}$ acetoacetate while only 4 out of 21 samples showing 0 contained more than $0.4 \mathrm{mM}$. Comparison of Ketostix readings with total blood ketone body content showed poor correlation. One reason for this was the large variation in the ratio of 3-hydroxybutyrate to acetoacetate in ketoacidosis; another was that often Ketostix had been stored in such a way that they had become damp, which impairs their reliability. If the Ketostix reading and estimation of the blood $\mathrm{pH}$ show a discrepancy we suggest that an enzymatic assay should be used to determine the ketone bodies and lactate.

\section{Introduction}

The estimation of blood "ketone bodies" (acetoacetate, 3hydroxybutyrate) as well as of blood glucose is needed for the assessment of the severity of diabetic coma. This measurement is also essential for the early exclusion of hyperosmolar non-ketotic diabetic coma. The initial insulin requirements are often based on the extent of the existing hyperketonaemia (Duncan and Gill, 1953; Hockaday and Alberti, 1972).

The accurate enzymatic measurement of blood ketone bodies takes at least two hours, and a more rapid method is required. An indication is given by the arterial blood $\mathrm{pH}$, but this can be misleading if acidaemia is due to lactic acid, and the blood buffering capacities of individuals differs widely. Ketostix has been used as a more specific measure of ketoacidosis (Watkins and Fitzgerald, 1968). It is rapid, the range is of the right magnitude, and added sensitivity can be gained by prolonging the incubation to 30 seconds. However, Ketostix is based on a nitroprusside method measuring acetoacetate and to a lesser extent acetone, but not 3-hydroxybutyrate. Thus when the

Radclifie Infirmary, Oxford K. G. M. M. ALBERTI, D.PHIL., B.M., B.CH., Research Officer, Nuffield

T. D. R. HOCKADAY, D.PHIL., F.R.C.P., Consultant Physician 3-hydroxybutyrate to acetoacetate ratio is abnormally high Ketostix will give a false low estimate of total ketone bodies (Marliss et al., 1970; Alberti et al., 1971).

We have used Ketostix in both the diagnosis and the management of 50 cases of diabetic coma and precoma, and have simultaneously estimated acetoacetate and 3-hydroxybutyrate enzymatically in whole blood. The results shown below indicate that the accuracy of Ketostix in practice is not so great as has previously been suggested (Watkins and Fitzgerald, 1968). Possible reasons for this and means for improving the accuracy are discussed. In addition, we report the results of direct enzymatic measurements of ketone bodies in plasma without previous deproteinization; this allows a rapid assessment of the degree of hyperketonaemia. A similar method has been described for rat plasma (McGarry et al., 1970).

\section{Methods}

\section{KETOSTIX}

The Ketostix strips used were those available in the wards and emergency room of the Radcliffe Infirmary. It was felt that these should be used, rather than a special supply, so as to reflect the practice in most hospitals. Ketostix readings were generally made by one of us but also include readings by both house staff and members of the department of clinical biochemistry. Readings were taken at 15 seconds and expressed as negative, trace,,+++ , and +++ . In some cases plasmas giving +++ readings were diluted 1 in 2 with tap-water and a further Ketostix estimation was made.

\section{ENZYMATIC METHOD FOR KETONE BODY ESTIMATION}

(a) Whole blood.-Immediately after it was drawn $5 \mathrm{ml}$ of venous blood was added to $5 \mathrm{ml}$ of $10 \%(\mathrm{w} / \mathrm{v})$ perchloric acid $\left(\mathrm{HClO}_{4}\right)$ and the mixture instantly refrigerated. Removal of the denatured proteins by centrifugation and neutralization of the supernatant with $30 \% \mathrm{KOH}$ to $\mathrm{pH} 7$ were performed within 72 hours. Acetoacetate was estimated immediately after neutralization and 3-hydroxybutyrate later. Venous blood acetoacetate and 3-hydroxybutyrate were estimated by enzymatic methods (Williamson et al., 1962). For acetoacetate a known volume of the neutralized supernatant $(0.05$ to $1 \mathrm{ml}$, depending on the expected acetoacetate content) was pipetted into a spectrophotometric cuvette and made up to $1 \mathrm{ml}$ with water, if necessary. To this was added $1 \mathrm{ml}$ of "cocktail" containing $1.25 \mathrm{ml}$ of $0.5 \% \mathrm{NADH}$ (reduced nicotinamide adenine dinucleotide) to every $25 \mathrm{ml}$ of $0 \cdot 1 \mathrm{M}$ potassium phosphate buffer, $\mathrm{pH} 7$. Two baseline spectrophotometric readings were then made at $340 \mathrm{~m} \mu$. Next $0.01 \mathrm{ml}$ of 3-hydroxybutyrate dehydrogenase (2.5 $\mathrm{mg} / \mathrm{ml}$; Boehringer Mannheim $\mathrm{GmbH}$, Germany) was 
added, the cuvettes were inverted three times, and readings were repeated after 30 minutes and then at five-minute intervals until no further change in optical density occurred. A blank was run with no addition of enzyme. If required, pyruvate can be determined before the acetoacetate by the addition of lactate dehydrogenase.

The estimation of 3-hydroxybutyrate is similar but the "cocktail" consists of $1 \mathrm{ml}$ of a mixture of $1 \mathrm{ml}$ of $100 \%$ hydrazine hydrate, $5 \mathrm{ml}$ of $\mathrm{N}$ hydrochloric acid, $14 \mathrm{ml}$ of $0.1 \mathrm{M}$ tris buffer, $\mathrm{pH} 8.5,25 \mathrm{mg}$ of EDTA (ethylenediamine tetra-acetic acid), and $1 \mathrm{ml}$ of $1 \%$ NAD (nicotine adenine dinucleotide). The same amount of 3-hydroxybutyrate dehydrogenase is used as for acetoacetate. The incubation is for 45 minutes with spectrophotometric readings then taken at 10-minute intervals until readings are constant.

Control experiments showed that there was no change in the apparent concentration of the ketone bodies after storage for up to five days of the perchloric acid and blood mixture at $0-4^{\circ}$ compared with immediate centrifugation, neutralization, and assay. In every case where there was a discrepancy between the enzymatic assay and the previous Ketostix reading the enzymatic assay was repeated.

(b) Deproteinized Plasma.-When plasma was used for enzymatic assays heparinized blood was centrifuged immediately at $0-4^{\circ}$ and $0.5 \mathrm{ml}$ of the separated plasma was added to $2 \mathrm{ml}$ of $3 \%(\mathrm{w} / \mathrm{v}) \mathrm{HClO}_{4}$ and subsequently treatment was as for whole blood. Plasma itself could be stored at $0-4^{\circ}$ for up to 24 hours without significant change in ketone body concentration, as has been noted by Gibbard and Watkins (1968).

(c) Non-deproteinized Plasma.-In some cases plasma was diluted 1 in 10 with water and 0.05 or $0.1 \mathrm{ml}$ used directly for enzymatic assay without previous deproteinization.

\section{Results}

\section{CALIBRATION OF KETOSTIX}

Solutions of acetoacetate, 3-hydroxybutyrate, and acetone in non-diabetic plasma were freshly prepared; acetoacetate concentrations ranging from 0.35 to $14 \mathrm{mM}$ and acetone and 3hydroxybutyrate concentrations ranging from 0.5 to $100 \mathrm{mM}$. Ketostix strips were incubated for 15 and 30 seconds. Results were extremely reproducible and are shown in Table I.

A trace reading on Ketostix covers the range 1 to $2 \mathrm{mM}$ acetoacetate, + indicates 2 to $3 \mathrm{mM},++$ indicates 4 to $7.5 \mathrm{mM}$, while +++ indicates a concentration of more than $10 \mathrm{mM}$ with incubation for 15 seconds. Incubation for 30 seconds increased the sensitivity to $0.5 \mathrm{mM}$ while dilution of plasma 1 in 2 and 1 in 4 with tap-water gave the expected readings. 3-Hydroxybutyrate concentrations up to $36 \mathrm{mM}$ did not interfere with the acetoacetate reaction with Ketostix. Acetoacetate values greater than $10 \mathrm{mM}$ are rarely, if ever, encountered clinically.

As expected 3-hydroxybutyrate gave entirely negative results

TABLE I-Ketostix Readings with Known Concentrations of Acetoacetate and Acetone in Plasma

\begin{tabular}{|c|c|c|c|c|c|c|c|}
\hline \multirow{2}{*}{\multicolumn{3}{|c|}{$\begin{array}{c}\text { Plasma } \\
\text { Acetoacetate } \\
\begin{array}{c}\text { Concentration } \\
(\mathrm{mM})\end{array}\end{array}$}} & \multicolumn{2}{|c|}{$\begin{array}{l}\text { Ketostix } \\
\text { Reading }\end{array}$} & \multirow{2}{*}{$\begin{array}{c}\begin{array}{c}\text { Plasma } \\
\text { Acetone } \\
\text { Concentration } \\
\text { (mM) }\end{array} \\
5 \\
10\end{array}$} & \multicolumn{2}{|c|}{$\begin{array}{l}\text { Ketostix } \\
\text { Reading }\end{array}$} \\
\hline & & & $\begin{array}{c}15 \mathrm{sec} \\
0 \\
0 \\
0\end{array}$ & $\frac{30 \mathrm{sec}}{0}$ & & $15 \mathrm{sec}$ & $30 \mathrm{sec}$ \\
\hline $\begin{array}{c}0.25 \\
0.5 \\
1.0 \\
2.0 \\
3.0 \\
4.0 \\
5.0 \\
7.5 \\
10.0 \\
15.0 \\
20.0\end{array}$ & $\begin{array}{l}\because \\
\therefore \\
\therefore \\
\therefore \\
\therefore \\
\therefore \\
\therefore\end{array}$ & $\begin{array}{l}\because \\
\because \\
\because \\
\because \\
\because \\
\cdots \\
\because \\
\therefore\end{array}$ & $\begin{array}{c}0 \\
0 \\
0 \\
+ \\
++ \\
++ \\
++ \\
++ \\
+++ \\
+++ \\
+++\end{array}$ & $\begin{array}{c}0 \\
\pm \\
+ \\
++ \\
++ \\
++ \\
++ \\
+++ \\
+++ \\
+++ \\
+++\end{array}$ & $\begin{array}{r}5 \\
10 \\
20\end{array}$ & $\begin{array}{c}0 \\
\pm \\
++\end{array}$ & $\begin{array}{l} \pm \\
+ \\
+\end{array}$ \\
\hline
\end{tabular}

Standard solutions of acetoacetate, acetone, or 3-hydroxybutyrate were added to normal plasma which contained less than $0.05 \mathrm{mM}$ total ketone bodies. Plasma hydroxybutyrate up to $100 \mathrm{mM}$ gave 0 readings. even at $100 \mathrm{mM}$. On the other hand, acetone gave positive readings; a level of $10 \mathrm{mM}$ giving a trace reading which would be equivalent in practical use of Ketostix to $1.5 \mathrm{mM}$ acetoacetate.

\section{RETOSTIX READING AND BLOOD ACETOACETATE LEVELS}

Ketostix readings plotted against enzymatically determined acetoacetate levels in patients are shown in Fig. 1. The limits determined in the laboratory for each Ketostix reading are also included (Table I).

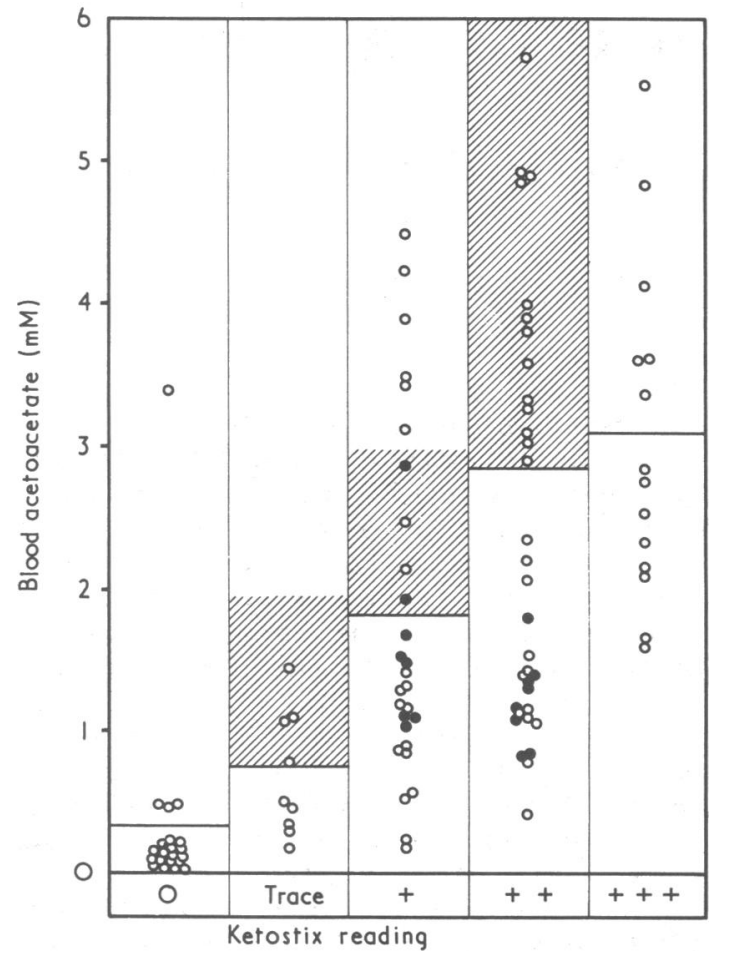

FIG. 1-Relation of Ketostix reading to blood acetoacetate concentration in diabetic patients. Thick bars show mean concentrations for undiluted samples; open circles, undiluted plasma readings; closed circles, plasma readings after dilution with an equal volume of water; hatched areas show the range obtained with known concentrations of acetoacetate added to plasma. This was above the diagram scale for +++ samples.

There is a considerable overlap in the range of acetoacetate concentrations between adjacent Ketostix grades, particularly in the + and ++ groups, thus the former covered a range from 0.2 to $4.5 \mathrm{mM}$ and the latter from 0.5 to $5.8 \mathrm{mM}$. All +++ samples contained more than $1.6 \mathrm{mM}$ acetoacetate and only 4 out of 21 samples showing 0 contained more than $0.4 \mathrm{mM}$ acetoacetate.

Each group contained several samples where the Ketostix reading was much lower than would have been expected from the acetoacetate values. It seems likely that some of these were because the Ketostix had been stored improperly or were too old.

In general the median for each group was lower than expected from the laboratory evaluation of the strip. Possibly this was because the enzymatic method was used for whole blood while Ketostix was used on plasma, and red cells may have a lower content of ketone bodies than plasma. Table II shows plasma and whole blood values for several samples. In most cases 3-hydroxybutyrate and acetoacetate are higher in plasma, as found for 3-hydroxybutyrate by Gibbard and Watkins (1968). Another reason for the discrepancy between predicted and achieved results is that blood from ketoacidotic patients may contain up to $13 \mathrm{mM}$ acetone (Sulway and Malins, 1970) and this would be equivalent to 2-3 $\mathrm{mM}$ acetoacetate. Variable amounts of acetone would also explain the wide scatter of results with the extent of the acetonaemia largely dependant on the duration of the coma. 
TABLE II-Plasma and Whole-blood Ketone Body Content. Venous Blood and Plasma Samples were Obtained from Patients and Treated as Described in the Text

\begin{tabular}{|c|c|c|c|c|c|}
\hline & \multirow{2}{*}{ Sample } & \multicolumn{2}{|c|}{ Acetoacetate (mM) } & \multicolumn{2}{|c|}{ 3-Hydroxybutyrate (mM) } \\
\hline & & Plasma & Whole Blood & Plasma & Whole Blood \\
\hline$\frac{1}{2}$ & $\begin{array}{l}\cdots \\
\because \\
\cdots \\
\cdots \\
\cdots\end{array}$ & $\begin{array}{l}0.07 \\
0.55 \\
1.19 \\
= \\
2.06 \\
3.28\end{array}$ & $\begin{array}{l}0.07 \\
0.47 \\
0.81 \\
= \\
2.04 \\
2.08\end{array}$ & $\begin{array}{l}0.16 \\
1.58 \\
1.91 \\
0.38 \\
3.95 \\
4.38 \\
7.92\end{array}$ & $\begin{array}{l}0.07 \\
1.16 \\
1.11 \\
0.32 \\
3.59 \\
3.78 \\
7.08\end{array}$ \\
\hline
\end{tabular}

\section{KETOSTIX READING AND BLOOD TOTAL KETONE BODY LEVELS}

Total ketone body levels showed even poorer correlation with Ketostix readings (Fig. 2). In particular there were several false low readings on Ketostix. This was due to high 3-hydroxybutyrate to acetoacetate ratios in several patients. Thus though the mean ratio was $5.2 \pm 0.9 \mathrm{mM}$, values ranged from 1.9 to 31.7 . In particular severely ill patients had higher ratios than the less ill patients. This is in contrast to the ratios of $2.73 \pm 0.73$ and $2.36 \pm 0.68$ found by Williamson et al. (1962) and Gibbard and Watkins (1968) in data gained primarily from fit patients, while Alberti et al. (1972) found a ratio of 1.50 in normal subjects. Seven of the 22 blood samples which gave negative readings on Ketostix contained appreciable amounts of ketone bodies, a $32 \%$ discrepancy rate.

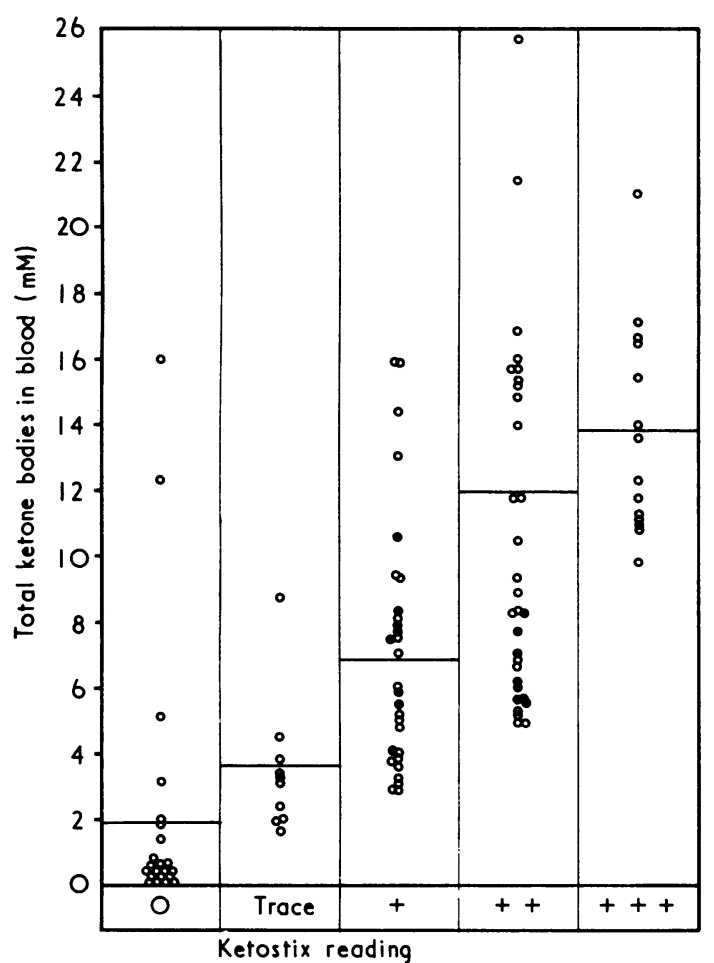

FIG. 2-Relation of Ketostix reading to total blood ketone body concentration. Thick bars show mean concentrations and refer to undiluted samples only; open circles, undiluted samples; closed circles, samples diluted 1 in 1 with water.

\section{RAPID ENZYMATIC ESTIMATION OF BLOOD KETONE BODIES}

In cases where the Ketostix reading is at variance with arterial $\mathrm{pH}$ and the clinical state of the patient it would be useful to estimate the blood ketone bodies more rapidly. At present it takes a minimum of $\mathbf{9 0}$ minutes. This can be shortened to $\mathbf{4 0}$ minutes if plasma is used directly and not deproteinized. This is of little use for low levels of ketone bodies, such as those found after an overnight fast in non-diabetic subjects, because of the
TABLE III-Correlation between Plasma Acetoacetate and 3-Hydroxybutyrate Measured Directly or after Plasma Deproteinization. Details of the Method are Given in the Text

\begin{tabular}{|c|c|c|c|c|c|}
\hline & \multirow{2}{*}{ Sample } & \multicolumn{2}{|c|}{ Acetoacetate (mM) } & \multicolumn{2}{|c|}{ 3-Hydroxybutyrate (mM) } \\
\hline & & Direct & Deproteinized & Direct & Deproteinized \\
\hline B & 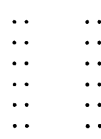 & $\begin{array}{l}0.9 \\
1.6 \\
2.7 \\
3.6 \\
4.5 \\
0.7\end{array}$ & $\begin{array}{l}1.0 \\
1.5 \\
2.5 \\
3.3 \\
4.4 \\
0.8\end{array}$ & $\begin{array}{r}3 \cdot 8 \\
6 \cdot 0 \\
10 \cdot 1 \\
20 \cdot 9 \\
29 \cdot 6 \\
32 \cdot 9\end{array}$ & \begin{tabular}{r|}
$3 \cdot 3$ \\
$6 \cdot 2$ \\
$10 \cdot 2$ \\
$21 \cdot 3$ \\
$29 \cdot 4$ \\
$37 \cdot 3$
\end{tabular} \\
\hline
\end{tabular}

high optical density of undiluted plasma. However, in hyperketonaemia plasma can be diluted tenfold and still give an accurate spectrophotometric reading. Table III shows values obtained for plasma from blood to which various concentrations of 3-hydroxybutyrate and acetoacetate were added, compared with conventional enzymatic assay on deproteinized plasma, which was used rather than whole blood because of the discrepancy between whole blood and plasma ketone body concentration already described. Comparable values were obtained at all concentrations tests. These cover the range within which values from coma patients usually occur. The results are at variance with those of McGarry et al. (1970), who found significantly lower levels in deproteinized plasma. They used equal volumes of plasma and perchloric acid and thus had bulkier protein precipitates. We have used 0.1 or $0.25 \mathrm{ml}$ of plasma in $1 \mathrm{ml}$ of perchloric acid. The time involved in the direct plasma estimation is no greater than that needed in many laboratories for the estimation of blood glucose.

\section{Discussion}

Ketostix as used in practice has proved less accurate in the measurement of plasma ketones than previously claimed. Three reasons are given for this. One is the improper care of Ketostix. If the bottle is not closed tightly the strips become damp, which impairs their effectiveness. This can be rectified by ensuring adequate renewal of bottles particularly in the emergency room. It would be helpful if the manufacturers were to incorporate some means whereby damp strips could be detected. The manufacturer's leaflet states that "Darkening of test areas may indicate loss of sensitivity." This requires a qualitative judgement and is difficult in artifical light. Our solution for the present is to test a strip from the bottle to be used against a standard acetone solution known to give a ++ reaction.

Another cause of inaccuracy is the variable acetone content in the blood of ketoacidotic patients-from 2.5 to $12.9 \mathrm{mM}$ (Sulway and Malins, 1970). This may be of benefit to the patient in that acetone plus acetoacetate may be a better guide to treatment than acetoacetate alone, and acetone should perhaps be taken into account when assessing ketonaemia to determine treatment. Clinically, the most confusing cause of inaccuracy is the large variation in the 3-hydroxybutyrate to acetoacetate ratio among ketoacidotic patients. Thus in a significant proportion of patients (perhaps 10 to $20 \%$ ) negative results will be obtained on Ketostix even when total ketone body levels are high. "This has been described by others, but unlike previous reports (Marliss et al., 1970; Alberti et al., 1971) we have found it to be commoner than lactic acidosis.

Ketostix is still useful in the initial assessment of the patient but blood $\mathrm{pH}$ should always be estimated as well. In the event of a discrepancy, such as a negative Ketostix with a $\mathrm{pH}$ of less than $7 \cdot 2$, we would suggest (1) the use of a fresh bottle of Ketostix and checking with a standard acetone solution, and (2) estimation of plasma acetoacetate and 3-hydroxybutyrate by the rapid enzymatic method with blood lactate measurement in addition where possible. Two situations may occur which could vitiate the direct enzymatic measurement of ketones in plasma: (1) when a highly lipaemic plasma gives too high a blank optical density, but adequate dilution will generally cope with this, and 
(2) when there is a raised concentration of lactate dehydrogenase. The latter would cause changes in optical density before the addition of the 3-hydroxybutyrate dehydrogenase, and is due to the conversion of plasma pyruvate to lactate with accompanying utilization of $\mathrm{NADH}$. In this situation perchloric acid extraction would have to be performed.

We thank Mrs. V. Illic, Miss H. Kuresova, and Miss S. Warne for technical help. We also acknowledge our debt to the admitting physicians of the Radcliffe Infirmary for allowing us to study patients under their care, and to the house staff for their cooperation. We are particularly indebted to Dr. D. H. Williamson for his advice, encouragement, and suggestions. K.G.M.M.A. is supported by the Wellcome Trust. Grants towards this work were also made by the British Diabetic Association and the National Health Service.
Requests for reprints should be sent to Dr. K. G. M. M. Alberti, Nuffield Department of Medicine, Radcliffe Infirmary, Oxford.

\section{References}

Alberti, K. G. M. M., Corbett, J., Hockaday, T. D. R., and Williamson, D. H. (1971). British Medical fournal, 1, 47.

Alberti, K. G. M. M., Record, C. O., Williamson, D. H., and Wright, R.

(1972). Clinical Science. In press.

Duncan, G. G., and Gill, R. J. (1953). Diabetes, 2, 353.

Hockaday, T. D. R., and Aiberti, K. G. M. M. (1972). British fournal of Hospital Medicine, 7, 183 .

McGarry, J. D., Guest, M. J., and Foster, D. W. (1970). Journal of Biological Chemistry, 245, 4382.

Marliss, E. B., Ohman, J. L., jun., Aoki, T. T., and Kozak, G. P. (1970). New England Yournal of Medicine, 283, 978.

Sulway, M. J., and Malins, J. M. (1970). Lancet, 2, 736

Watkins, P. J., and Fitzgerald, M. G. (1968). Diabetes, 17, 398.

Williamson, D. H., Mellanby, J., and Krebs, H. A. (1962). Biochemical fournal, 82, 90 .

\title{
Successful use of Oral Diazoxide in the Treatment of Severe Toxaemia of Pregnancy
}

\author{
J. E. F. POHL， H. THURSTON， D. DAVIS， M. Y. MORGAN
}

British Medical Fournal, 1972, 2, 568-570

\section{Summary}

Treatment with oral diazoxide for periods of 4 to 10 weeks in hospital allowed adequate control of hypertension with continuation of fetal growth in four patients with severe toxaemia. Two were insulin-dependent diabetics and one of these suffered from renal failure. In all patients albuminuria diminished markedly, while the fluid retention was controlled with frusemide. Three pregnancies were successfully terminated by lower segment caesarean section and in the remaining case vaginal delivery resulted in the birth of a healthy baby. Control of blood sugars presented no problems in the diabetic patients. Only minimal adjustments of insulin dosage were required. One of the non-diabetic patients developed mild hyperglycaemia which responded to tolbutamide. The babies, ranging in age from 5 to 12 months, have continued to thrive.

\section{Introduction}

The successful management of severe toxaemia of pregnancy demands the control of the raised blood pressure as well as the

Diazoxide Dosage, Associated Maternal Condition, and Age of Babies

\begin{tabular}{|c|c|c|c|}
\hline $\begin{array}{l}\text { Case } \\
\text { No. }\end{array}$ & Diazoxide & Age of Infant & $\begin{array}{c}\text { Associated Maternal Medical } \\
\text { Condition }\end{array}$ \\
\hline 1 & 100 mg q.d.s. & 12 months & $\begin{array}{l}\text { Diabetes mellitus. Kimmelstiel- } \\
\text { Wilson syndrome }\end{array}$ \\
\hline $\begin{array}{l}2 \\
3 \\
4\end{array}$ & $\begin{array}{l}250 \mathrm{mg} \text { q.d.s. } \\
100 \mathrm{mg} \text { t.d.s. } \\
2.00 \mathrm{mg} \text { q.d.s. }\end{array}$ & $\begin{array}{ll}6 & \prime \prime \\
5 & \Rightarrow\end{array}$ & $\begin{array}{l}\text { Diabetes mellitus } \\
\text { Infertile } 9 \text { years }\end{array}$ \\
\hline
\end{tabular}

\section{Manchester Royal Infirmary, Manchester 13}

J. E. F. POHL, M.B., B.S., M.R.C.P., Lecturer in Therapeutics H. THURSTON, M.B., CH.B., M.R.C.P., Lecturer in Medicine D. DAVIS, M.B., CH.B., M.R.C.P., Lecturer in Endocrinology

St. Mary's Hospital, Whitworth Park, Manchester 13

M. Y. MORGAN, M.B., CH.B., Senior House Officer in Obstetrics and Gynaecology (At present Senior House Officer in Medicine, Stepping Hill Hospital, Stockport) maintenance of adequate placental perfusion and renal function. Conventional therapy achieves only the first of these objectives. Intravenous diazoxide has been reported by Finnerty (1962) to produce favourable results in toxaemia of pregnancy. We wish to report the successful use of oral diazoxide in four patients presenting with severe toxaemia of pregnancy (see Table).

\section{Case 1}

A 24-year old insulin-dependent diabetic of 12 years' standing was first documented as having albuminuria with mild hypertension eight years previously. She presented to this hospital in June 1970 in the third month of her second pregnancy with a blood pressure of $130 /$ $90 \mathrm{~mm} \mathrm{Hg}$, proteinuria, but without oedema or retinopathy. Her blood urea was $28 \mathrm{mg} / 100 \mathrm{ml}$. In July 1970 at 17 weeks her blood urea had risen to $54 \mathrm{mg} / 100 \mathrm{ml}$, and the serum creatinine was $2.0 \mathrm{mg} / 100 \mathrm{ml}$.

Early in August she was readmitted with a haemoglobin of $9.0 \mathrm{~g} /$ $100 \mathrm{ml}$, for a total dose infusion of Imferon. This was ineffective, however, and by the end of September, when her haemoglobin had fallen to $7 \cdot 2 \mathrm{~g} / 100 \mathrm{ml}$, she was transfused with 2 pints $(1,140 \mathrm{ml})$ of packed cells. Later in August her final admission was precipitated by progressive hypertension (135/100), increasing albuminuria, and the development of dependent oedema. Retinal haemorrhages were observed for the first time.

She was treated with heavy sedation and strict bed rest, but did not improve. In September, at the twenty-sixth week of pregnancy, her blood pressure was 180/110, and she had generalized oedema, hydramnios, a raised jugular venous pressure, and hepatomegaly. There were fresh haemorrhages in both fundi. The blood urea was $54 \mathrm{mg} /$ $100 \mathrm{ml}$, the urinary protein leak was $4 \mathrm{~g}$ per 24 hours and the serum albumin was $2.9 \mathrm{~g} / 100 \mathrm{ml}$. Termination of pregnancy was considered but a trial of diazoxide was held to be a justifiable alternative. Treatment with oral diazoxide $50 \mathrm{mg}$ three times a day increasing to 100 $\mathrm{mg}$ four times a day was begun and her blood pressure fell to 110/70 and was maintained near that level for the remaining 10 weeks of her pregnancy. Her urinary protein leak fell to 0.5 to $1 \mathrm{~g}$ a day. The fluid retention was overcome by the use of up to $200 \mathrm{mg}$ of frusemide daily but there was no consistent effect on the hydramnios.

The diabetic control was maintained with twice-daily injections of a mixture of soluble and isophane insulin. After the introduction of diazoxide an increase from 4 to 8 units total daily dose of insulin was required. The only discomfort the patient suffered during the remainder of her pregnancy was the well-known side effect of nausea and occasional vomiting. The persistent hydramnios may well have been a 